\title{
Current status of zinc in health and disease states
}

\author{
P. J. AGGETT AND J. T. HARRIES
}

\author{
Institute of Child Health, London
}

Even though brass, a zinc-copper alloy, had been known for centuries, metallic zinc was not isolated in Europe until 1509. The metal was then named zinken because of its superficial similarity to tin (German-zinn) (Wootton, 1910).

Zinc (atomic number 30 ; atomic weight $65 \cdot 37$ ) has a completed d subshell with $2 \mathrm{~s}$ electrons and the divalent cation is the only naturally occurring oxidation state. This relative stability, its ability to co-ordinate 4 or occasionally 6 ligands, and its capacity to act as a Lewis acid are probably fundamental to zinc's biological role. The biological importance of zinc was first discovered when Raulin (1869) demonstrated that it was necessary for the growth of Aspergillus niger. Subsequently, the ubiquitous distribution of zinc in nature was appreciated and the essentiality of zinc for higher plants (Mazé, 1914) and animals (Todd et al., 1934) was established.

In man the medicinal use of calamine (zinc carbonate) is first recorded in Papyrus Ebers of 1550 BC (Ebers, 1937) but it was not until 1939 that it was suggested that zinc deficiency might contribute to the clinical manifestations of human vitamin deficiency syndromes such as beriberi (Eggleton, 1939). The first human zinc deficiency syndrome was identified in the early $1960 \mathrm{~s}$ in malnourished adolescent boys in Iran and Egypt (Halsted et al., 1972). A more profound deficiency state became apparent when Moyanhan and Barnes (1973) showed that treatment with zinc induced a complete and rapid clinical remission in a patient with acrodermatitis enteropathica.

\section{Dietary sources and requirements}

Good dietary sources of zinc (Underwood, 1977) are meat $(20-60 \mu \mathrm{g}(0 \cdot 3-0.9 \mu \mathrm{mol}) / \mathrm{g}$ wet weight, and fish $(15 \mu \mathrm{g}(0.2 \mu \mathrm{mol}) / \mathrm{g}$ wet weight $)$. Although cereals

Centre for Study of Metabolism of Trace Elements, University of Aberdeen

P. J. AGGETT, co-ordinator

Institute of Child Health, London

J. T. HARRIES, reader in paediatrics and vegetables have similar zinc contents $(15-60 \mu \mathrm{g} / \mathrm{g}$ wet weight) to meats, the bioavailability of zinc from plant sources is reduced by their high phytate (inositol hexaphosphate) content which complexes the metal and prevents its absorption (Becker and Hoekstra, 1971). Diets containing phytate and zinc with a molar ratio in excess of 25:1 induce growth retardation in young rats (Davies and Oppin, 1979). Momcilovic et al. (1976) showed that the availability of zinc from a soya-based infant feed may be reduced by $20 \%$. Complexation also occurs with fibre, hemicellulose, and clay; cellulose bulking agents reduce the absorption of the radioisotope ${ }^{65} \mathrm{Zn}$ (Becker and Hoekstra, 1971). Both calcium and phosphate reduce the utilisation of dietary zinc. Chelating agents such as EDTA, and animal protein may improve zinc availability from plant materials (Becker and Hoekstra, 1971), and its content in and availability from foodstuffs may be altered during food preparation (Halsted et al., 1974).

The zinc content of cows' and human milk is variable (Picciano and Guthrie, 1976) and comparisons are unreliable. Human milk contains a low molecular weight zinc-binding ligand which probably facilitates absorption (see later); such a ligand is not present in cows' milk and zinc from this source to the human infant may be reduced (Eckhert et al., 1977). A recent study on 6-month-old infants showed higher plasma zinc levels in those which were breast fed than in infants fed cows' milk-based formulae (Hambidge et al., 1979). A longitudinal study has demonstrated that human breast milk zinc concentrations decrease with the duration of lactation (Vuori and Kuitunen, 1979). These are facts that need to be considered when evaluating the zinc nutritional value of infant feeds and of mature breast milk, especially when it is given to preterm infants in whom absorptive mechanisms may be immature (see later).

An adult consumes 10-15 mg (Underwood, 1977) of dietary zinc a day and the following age- and sex-related daily dietary allowances have been recommended by the National Research Council 
Food and Nutrition Board (1974): 0-6 months, $3 \mathrm{mg}$ (46 $\mu \mathrm{mol}) ; 6-12$ months, $5 \mathrm{mg}$ (76 $\mu \mathrm{mol}) ; 1-10$ years, $10 \mathrm{mg}(152 \mu \mathrm{mol})$; adolescent children, adult men, and nonpregnant women, $15 \mathrm{mg}(230 \mu \mathrm{mol})$; pregnant women, $20 \mathrm{mg}(305 \mu \mathrm{mol})$, and lactating mothers $25 \mathrm{mg}(382 \mu \mathrm{mol})$. A WHO Expert Committee (World Health Organisation, 1973) prepared recommendations based on the bioavailability of dietary zinc but all such recommendations can only serve as tentative guidelines. In healthy children in the UK, Alexander et al. (1974) demonstrated an average daily intake of $0.3 \mathrm{mg}$ $(4 \cdot 6 \mu \mathrm{mol}) / \mathrm{kg}$; about $20 \%$ of which was absorbed.

\section{Absorption}

Zinc absorption occurs throughout the small intestine but most rapidly in the duodenum and proximal jejunum (Methfessel and Spencer, 1973), and is probably a carrier-mediated process (Davies, 1974). In vitro uptake studies in human small intestinal mucosa suggest that it is also an active energy-dependent process (Atherton et al., 1979) and isopycnic ultracentrifugation studies (unpublished) on isolated enterocytes from this material indicate that the absorbed zinc is almost totally distributed in the cytosol fraction. ${ }^{65} \mathrm{Zn}$ can be detected in plasma 15 minutes after ingestion and reaches a peak 4 hours later (Spencer et al., 1966); patients with an ileojejunal bypass appear to have reduced zinc absorption (Andersson et al., 1976).

Low molecular weight (8000-10 000) zinc-binding ligands (ZBL) have been reported in the small intestine and pancreas of rats, in the pancreatic secretions of dogs (Evans, 1976a), and in rat and human milk (Hurley et al., 1978). Although the precise functions of these ZBL have not been defined, they almost certainly facilitate zinc absorption from the intestinal lumen. The mucosal ZBL is absent in the newborn rat which is dependent on the maternal milk ZBL for optimum zinc absorption. This dependence is lost after 18 days, by which time the mucosal ZBL has developed and the exogenous ZBL no longer enhances zinc absorption (Duncan and Hurley, 1978). A similar process may operate in the human since some term and low birthweight preterm infants have an impaired capacity to absorb zinc (Cavell and Widdowson, 1964; Dauncey et al., 1977) and the human breast milk ZBL content is highest in colostrum and diminishes thereafter (Hurley et al., 1978).

A low molecular weight cytoplasmic zinc-metalloprotein designated zinc-metallothionein (Zn-MTN) because of its high cysteine content, has been identified in the liver and small intestinal mucosa (Cherian and Goyer, 1978), and its synthesis can be induced by parenteral or oral administration of zinc (Richards and Cousins, 1975). Its precise function is undefined but it may participate in the homeostatic regulation of zinc metabolism and absorption, and provide a source of zinc at times of deprivation. The relationship between ZBL and intestinal Zn-MTN has not been clarified. Zn-MTN may regulate zinc absorption by sequestering zinc within the enterocyte. This possibility is supported by the observation that there is an inverse relationship between intestinal zinc uptake and intestinal MTN content (Richards and Cousins, 1976). It has been suggested that zinc is taken up from the enterocyte basolateral membrane by transferrin and conveyed to the liver via the portal vein (Evans, 1976a, b). The mechanism of cellular uptake of zinc and its incorporation into metalloproteins has not been elucidated but the latter probably occurs after the synthesis of the apoprotein.

\section{Excretion}

The main excretory route for zinc is in the faeces (Underwood, 1977). Biliary losses are small but pancreatic secretion may contribute $25 \%$ of endogenous zinc loss (Stake et al., 1974). The relative contributions to the remaining faecal loss by desquamation of surface epithelial cells or intestinal secretion has not been defined.

Renal conservation of zinc results in a daily urinary loss $<600 \mu \mathrm{g}(<9 \cdot 2 \mu \mathrm{mol})$ (Underwood, 1977). The zinc concentration in neonatal urine may be 5 times that of adults (Cavell and Widdowson, 1964).

Sweat zinc loss is negligible in preadolescent children studied in temperate areas (Harrison et al., 1975), but in tropical climates it may be significant. Secretion by this route is reduced with acclimatisation and in zinc deficiency states (Prasad et al., 1963).

\section{Body zinc distribution and mobilisation}

A $70-\mathrm{kg}$ man contains $1 \cdot 4-2 \cdot 3 \mathrm{~g}(21-35 \mathrm{mmol})$ of zinc (Widdowson et al., 1951) and a term neonate has about $60 \mathrm{mg}(0.9 \mathrm{mmol})$ (Widdowson and Spray, 1951). In the adult, this amount is about $40 \%$ of the total body content of iron and 10-20 times that of copper; there is relatively less zinc in the neonate and the corresponding ratios are $20 \%$ and 5 times respectively. Next to potassium, calcium, and magnesium, zinc is the most abundant intracellular metal and is located principally in the supernatant, microsomal, and nuclear fractions (Thiers and Vallee, 1957). Highest tissue concentrations $(>500$ $\mu \mathrm{g}(>7.7 \mu \mathrm{mol}) / \mathrm{g}$ dry weight) are found in the uveal tract, and postpubertal prostate gland and seminal fluid. Hair, nails, skin, and bones have a zinc 
content of $90-250 \mu \mathrm{g}(1 \cdot 4-3 \cdot 8 \mu \mathrm{mol}) / \mathrm{g}$, and the pancreas, liver, kidney, and muscle contain 140-230 $\mu \mathrm{g}(2 \cdot 1-3 \cdot 5 \mu \mathrm{mol}) / \mathrm{g}$ (Halsted et al., 1974). Muscles in newborn animals have a similar zinc content but active muscle groups soon develop higher concentrations than less active groups (Cassens et al., 1967).

Studies using ${ }^{65} \mathrm{Zn}$ show poor exchange of zinc deposited in bone, skin, and muscle and poor zinc mobilisation from these sources in rats at times of increased requirements, such as pregnancy (Hurley and Swennerton, 1971), suggest that these tissues which collectively contain $70-80 \%$ of the total body content of zinc do not provide an effective storage depot. In the young growing animal, however, release of bone zinc during the remodelling process may provide a reserve source (Brown et al., 1978). The fetal zinc content increases in proportion to body weight and there is little evidence of intrauterine storage of the element; however the possibility that hepatic zinc in the neonate may provide an additional store remains to be elucidated.

Erythrocyte zinc (10-14 $\mu \mathrm{g} / \mathrm{g}$ ) (Halsted et al., 1974 ) is predominantly located in the enzyme carbonic anhydrase and comprises $75-88 \%$ of the whole blood zinc content, the remainder being principally in the leucocytes $(3 \%)$ and plasma (12-20\%) (Vallee and Gibson, 1948); individual leucocytes contain about 25 times as much zinc as erythrocytes. Most of the plasma zinc is bound to albumin (50\%) and an $\alpha_{2}$-macroglobulin (30-40\%), a small amount is associated with a $\beta$-globulin (transferrin) and with free amino-acids (2-8\%) (Prasad and Oberleas, 1970).

Analytical values of plasma zinc vary slightly with the technique used for their assay but most laboratories providing such a service have determined their own normal range. The paediatric range established at The Hospital for Sick Children, London (Aggett et al., in preparation) is 11-24 $\mu \mathrm{mol} / 1$ (72-157 $\mu \mathrm{g} / 100 \mathrm{ml})$.

Plasma zinc levels fall within hours of stress-such as surgery, trauma, or inflammation-and remain low with chronic stress. This is caused by a protein, leucocyte endogenous mediator (LEM), which is released from activated phagocytes and which enhances hepatic uptake of zinc and iron as well as synthesis of acute phase proteins including caeruloplasmin (Beisel et al., 1976). Zinc is redistributed among its plasma ligands, and increased binding to low molecular weight ligands such as amino-acids may underlie the zincuria which can accompany stress. It is unclear at present whether LEM is a number of similar proteins or a single multifunctional entity. Plasma zinc levels are also frequently depressed in patients with neoplasia.

\section{Assessment of zinc status}

There is no reliable means currently available for determining the body zinc status in routine clinical practice. Plasma zinc levels are subject to acute variations and a single low value should be interpreted cautiously in conjunction with other factors, such as the patient's clinical condition. Serum levels are $16 \%$ higher than plasma levels partly as a result of the release of zinc from platelets and unavoidable haemolysis (Foley et al., 1968). Hair zinc levels correlate poorly with plasma levels but provide historical information which is of value in epidemiological studies. Low hair zinc levels in one study were associated with zinc-responsive symptoms (Hambidge et al., 1972) and probably represented previous zinc nutritional status. The interesting report of Heinersdorff and Taylor (page 958) showing a lower hair zinc content in boys aged 10-11 compared with similarly aged girls may reflect other, possibly physiological, influences which merit further investigation. Erythrocyte or leucocyte zinc determinations may prove to be more reliable then plasma levels, but the fact that the erythrocyte zinc content rises progressively during the first 12 years of life (Berfenstam, 1952) limits its application in children. Determination of urinary zinc is also unreliable, but it has been suggested that the urinary sulphate content could be of some value (Hsu and Anthony, 1971). In some studies salivary zinc has been measured (Henkin et al., 1975a). Tissue analysis, ${ }^{65} \mathrm{Zn}$ turnover, and balance studies are essentially research tools. It should be stressed that all specimens for zinc determination must be collected with great care and stored in zinc-free containers to avoid haemolysis and contamination. Reduced activity of zinc-dependent enzymes, such as alkaline phosphatase, often accompanies a reduction in plasma zinc in deficiency states, and may provide a valuable clue particularly when facilities for determining zinc are not readily available. At present, the best criterion of zinc deficiency is an unequivocal clinical response to zinc administration.

\section{Biological functions}

Enzyme activities. Zinc is essential for the activity of at least 90 enzymes which participate in all the major metabolic pathways. Over $\mathbf{4 0}$ metalloenzymes exist in which zinc is bound tightly to the apoenzyme in specific stoichiometric ratios and in which it serves one or more structural, regulatory, or catalytic functions (Riordan and Vallee, 1976). Mammalian metalloenzymes include carbonic anhydrase, carboxypeptidases, aminopeptidases, alkaline phosphatase, alcohol, retinol, malate, lactate, glutamate, and glyceraldehyde-3-phosphate dehydrogenases. Some 
metalloenzymes require additional metals for activity, cytosolic superoxide dismutase, for example, has a requirement for copper as well as for zinc.

Other metalloenzymes have only been identified in lower species and the particular metal dependence of an enzyme varies between species. Both DNA and RNA polymerases are zinc metalloenzymes in Escherichia coli; it has not been established that these are metalloenzymes in mammals but studies on animals indicate that thymidine kinase activity and nucleic acid synthesis are zinc-dependent in mammals. In some oncogenic viruses the reverse transcriptase (that is, RNA-dependent DNA polymerase) is a zinc metalloenzyme (Vallee, 1977). There is evidence that zinc is important for optimal activity of aspartate transcarbamylase, daminolaevulinic acid dehydratase activities (Riordan and Vallee, 1976), ornithine transcarbamylase (Rabbani and Prasad, 1978), and in fatty acid metabolism (Hambidge et al., 1978).

Zinc-deficient animals have impaired collagen synthesis and poor wound healing. This may reflect a generalised defect in protein and nucleic acid synthesis; however some evidence suggests that zinc deficiency alters the quantity and type of collagen cross links (Fernandez-Madrid et al., 1976).

Cell function. Zinc is essential for all phases of the cell cycle, but, as yet, there is little evidence to relate this directly to its effects on nucleic acid and protein synthesis. Deficiency is associated with RNA disaggregation and increased ribonuclease activity (Prasad and Oberleas, 1973), and the ability of zinc to inhibit adenylate cyclase and phosphodiesterase may indicate a role in cell function and genetic expression by regulating the relative intracellular concentrations of cyclic-AMP and cyclic-GMP (McMahon, 1974). Cell replication rates in the oesophagus and pancreas of zinc-deficient rats are increased (Fell et al., 1973), suggesting that a loss of genetic regulation precedes an effect on nucleic acid and protein synthesis. In human lymphocytes zinc acts as a mitogen, but here again the mechanism is unclear but appears to be mediated ${ }^{\top}$ by monocytes (Rühl and Kirchner, 1978). Zinc stabilises plasma and subcellular membranes (Chvapil, 1976) as well as nucleic acids and microtubules (Nickolson and Veldstra, 1972); it stabilises lysosomes and high concentrations in vitro inhibit leucocyte mobility and phagocytosis while enhanced macrophage migration has been described in zinc-deficient guinea-pigs (Chvapil, 1976); membrane lipid peroxidation is increased in zinc deficiency states, and it has been proposed that zinc protects membranes from free radical oxidation (Lancet, 1978).
Endocrine function. Insulin is stored in the $\beta$-cells of the pancreas as a hexamer with 2 atoms of zinc (Adams et al., 1969), and zinc appears to influence insulin binding and degradation at the hepatocyte plasma membrane (Arquilla et al., 1978). In some studies impaired glucose tolerance and insulin response have been associated with zinc deficiency, but this has not been a consistent feature (Kirchgessner et al., 1976).

Prostatic androgen metabolism is modified by the intracellular concentration of zinc, and both high and low tissue concentrations inhibit the transformation of testosterone to dihydrotestosterone (DHT) (Habib, 1978). Hartoma et al. (1977) demonstrated improved sperm counts and testosterone levels in hypozincaemic oligospermic males as a result of zinc administration; this treatment has also reversed uraemic impotence and increased DHT levels in patients with renal dialysis (Antoniou et al., 1977).

Taste. It has been suggested that zinc may play a physiological role in taste (Henkin et al., 1975a, b) and in this context is it of interest that 2 similar zinc metallo-proteins, gustin and nerve growth factor, have been isolated from human and murine saliva respectively and appear to combine with their respective taste buds and to be essential for their normal morphology and optimum function (Henkin, 1978).

\section{Zinc deficiency states}

Zinc deficiency can result from an inadequate dietary intake, malabsorption, increased body losses, intravenous feeding, or a combination of

\section{Table 1 Causes of zinc deficiency}

\begin{tabular}{l} 
Inadequate dietary intake \\
Protein-calorie deficiency \\
Vegetarianism \\
Patients on protein-restricted diets \\
Synthetic diets \\
Malabsorption \\
Acrodermatitis enteropathica \\
Coeliac disease and other enteropathies \\
Pancreatic insufficiency \\
Chronic inflammatory bowel disease \\
Immaturity of absorptive systems \\
Increased body losses \\
Starvation \\
Burns \\
Diabetes mellitus \\
Ketoacidosis \\
Diuretic treatment \\
Proteinuria \\
Hepatic disease \\
Intravascular haemolysis (for example, sickle cell anaemia) \\
Porphyria \\
Chelating agent therapy \\
Chronic blood loss \\
Parasitic infection \\
Dialysis \\
Exfoliative dermatitis \\
Excessive sweating \\
Intravenous feeding \\
\hline
\end{tabular}


several of these predisposing factors. Some examples are listed in Table 1; in some instances there is no conclusive evidence of zinc deficiency (see above) but all constitute 'at risk states' and have been associated with markedly reduced plasma or serum zinc levels, some of which deserve comment.

Inadequate dietary intake. Protein-calorie malnutrition in the developing parts of the world is probably the most common cause of zinc deficiency, but Western populations may be at risk from a marginal zinc intake. This may be the case in vegans, vegetarians (Bodzy et al., 1977), low socioeconomic groups subsisting on low meat diets (Hambidge et al., 1972, 1976), and patients with chronic renal disease on low protein diets (Rose and Willden, 1972). Synthetic diets used in the treatment of children with inborn errors of metabolism and dietary intolerances require zinc supplements (Alexander et al., 1974; Thorn et al., 1978), and this may be the case for soya-based infant formulae although it has not yet been assessed. It is conceivable that the ingestion of texturised vegetable protein meat extenders and other novel protein sources, or calorie-controlled diets may be at risk. The need for fuller evaluation of feeding practices is stressed by the work of Walravens and Hambidge (1976) who demonstrated an improved growth rate in baby boys receiving standard formulae containing zinc supplements.

Malabsorption. Defective absorption of zinc may be secondary to the immaturity of its absorption systems, as may be the case in newborn babies especially if preterm (Dauncey et al., 1977). Any individual with gastrointestinal disease is potentially at risk of developing zinc deficiency, particularly if the condition is long standing. Deficiency may result from intraluminal binding of zinc to high affinity ligands, impaired secretion of pancreatic $\mathrm{ZBL}$, defective uptake into mucosa, reduced mucosal ZBL, or increased secretion into the intestinal lumen. The pathophysiological mechanisms which operate in the genesis of zinc deficiency in various disorders of the gastrointestinal tract present an important and challenging area for future research.

In 1973 Moynahan and Barnes made the important discovery that all the clinical manifestations of acrodermatitis enteropathica (AE) resolved strikingly with oral zinc treatment (Moynahan, 1974). This historic discovery undoubtedly added a major motivation and impetus to research concerned with zinc in health and disease states in man. Impaired ${ }^{65} \mathrm{Zn}$ absorption has been shown in $\mathrm{AE}$ (Lombeck et al., 1975), and balance studies have shown that patients are in a net negative state with respect to zinc, and that this is accounted for by increased faecal losses (Aggett et al., 1978). Although these observations suggest malabsorption of zinc, they do not define the pathogenesis of malabsorption. We have demonstrated a pronounced defect in the in vitro uptake of zinc in jejunal biopsies obtained from patients with $\mathrm{AE}$, both when they are in remission and relapse (Atherton et al., 1979). Thus the primary abnormality in AE may be defective zinc uptake into the enterocytes and the condition represents an addition to the known selective inborn errors of absorption (Harries, 1977). Recently preliminary evidence of defective zinc binding by duodenal juice of patients with $\mathrm{AE}$ has been reported (Casey et al., 1978).

Increased body losses. Increased body losses may occur in a wide variety of conditions, as shown in Table 1.

Intravenous feeding. Intravenous feeding, particularly if prolonged, carries a risk of zinc deficiency. This is in part secondary to the variable but low content of zinc in the administered solutions (van Caillie et al., 1978) and to the excessive urinary losses of zinc complexed with carbohydrates or amino-acids, or both (Freeman et al., 1975). It is particularly likely to occur during an anabolic phase where there is an abrupt increase in body requirements and it is important to monitor zinc status during and after reintroduction of oral feeding (Fleming et al., 1976).

\section{Clinical manifestations of zinc deficiency}

The variable and protean clinical manifestations of zinc deficiency are listed in Table 2. Anorexia, growth retardation, and impaired taste and olfactory sensation, are early features as is mood alteration. Most neurological features have been described in adults with induced zinc deficiency (Henkin et al., 1975b); jitteriness and altered behaviour have been

Table 2 Clinical manifestations of zinc deficiency

Anorexia
Impaired taste and smell
Pica
Growth retardation
Hypogonadism
Impotence in renal dialysis patients
Depression, mood lability, impaired concentration
Intention tremor
Nystagmus
Dysarthria
Jitteriness
Photophobia, night blindness, blepharitis
Skin lesions (digits, perineum, parietal, nasolabial folds)
Paronychiae with monilial superinfection
Nails (growth arrest, loss, Beau's lines)
Hair growth arrest or alopecia
Delayed wound healing
Diarrhoea


reported in infants (Sivasubramanian and Henkin, 1978). Cutaneous signs range from a rough skin to a severe eczematous dermatitis affecting the digits, perineum, mouth, and nasolabial folds.

The biochemical consequences of zinc deficiency in human adults include reduced plasma alkaline phosphatase and lactate dehydrogenase activities, raised plasma ammonia, and increased plasma ribonuclease activity (Prasad et al., 1978b).

Impaired night vision might be more associated with impaired retinol dehydrogenase activity (Huber and Gershoff, 1975) than with any specific effect zinc deficiency may have on retinol-binding protein synthesis (Carney et al., 1976).

Impaired cell-mediated immunity with poor lymphoblast response, absent skin sensitivity reactions (Golden et al., 1978), thymic hypoplasia (Golden et al., 1977), and defective monocyte and polymorphonuclear leucocyte mobility have been associated with zinc deficiency and may contribute to the infections which occur particularly in patients with AE (Weston et al., 1977).

In the pregnant rat even transient zinc deficiency results in an increased incidence of fetal resorption, stillbirths, and abnormalities of the CNS, skeleton, lung, urogenital tract, and palate in the offspring; moreover, the newborn rats tend to be of low birthweights with altered learning and behavioural patterns (Hurley and Mutch, 1973). The last features have also been described in rhesus monkeys (Sandstead et al., 1978). The one abortion and the 2 congenital abnormalities reported in the 7 recorded pregnancies of 3 women with $\mathrm{AE}$ suggest that similar effects may apply to the pregnant human (Hambidge et al., 1975). It has been speculated that the high incidence of anencephaly in some Middle Eastern countries may be the result of environmental zinc deficiency (Sever and Emanuel, 1973). Serum zinc levels in women having abnormal deliveries or low birthweight or preterm infants were lower than in women not experiencing such abnormalities (Jameson, 1976). A causal relationship was not established however.

\section{Treatment of deficiency states}

Zinc can be administered as a sulphate $(22.5 \mathrm{mg}$ $(350 \mu \mathrm{mol})$ of elemental $\mathrm{Zn} / 100 \mathrm{mg})$, acetate $(30 \mathrm{mg}$ $(460 \mu \mathrm{mol}) \mathrm{Zn} / 100 \mathrm{mg})$, or oxide $(80 \mathrm{mg}(1 \cdot 2 \mathrm{mmol})$ $\mathrm{Zn} / 100 \mathrm{mg}$ ) salts. Zinc gluconate preparations are also used. In some individuals the salt, particularly the sulphate, can be irritant to the gastrointestinal tract and in these circumstances the zinc salt may be taken with a meal or capsulated preparations may be better tolerated; but zinc is less efficiently absorbed with meals and from capsules (Oelshlegel and
Brewer, 1977). These zinc salts have a wide therapeutic index and their doses should be adjusted according to the clinical response. In deficiency states an initial daily dose of $15 \mu \mathrm{mol}$ elemental $\mathrm{Zn} / \mathrm{kg}$ is given orally, or $5 \mu \mathrm{mol} / \mathrm{kg}$ IV. For maintenance IV therapy $2 \mu \mathrm{mol} / \mathrm{kg}$ is given daily at first. Larger oral doses are necessary in patients with AE. Plasma zinc and copper should be monitored frequently in these circumstances.

Zinc salts have also been used in the treatment of gastric ulcers (Frommer, 1975), rheumatoid arthritis (Simkin, 1976), and acne (Michaëlsson et al., 1977). These applications await further evaluation and the consequences of prolonged oral zinc administration (see below) indicate that such use of zinc should be undertaken cautiously.

\section{Toxicity}

Zinc salts are usually well tolerated, but toxic effects have been associated with oral ingestion of elemental zinc (Murphy, 1970), zinc sulphate capsules (Moore, 1978), the use of water from galvanised containers for drinking (Brown et al., 1964) and home dialysis (Gallery et al., 1972), sucking zinc alloy toys (Chunn, 1973), prolonged oral zinc supplements (Prasad et al., 1978a), and intravenous overdosage (Brocks et al., 1977). Symptoms include anorexia, nausea, vomiting, lethargy, dizziness, diarrhoea, and bleeding gastric erosions; raised serum amylase and lipase were noted by Murphy (1970), and copper deficiency with hypochromic anaemia with reduced plasma copper concentrations have been reported after prolonged treatment with oral zinc. Intravenous overdosage has been associated with acute renal failure and death. Contact dermatitis to zinc salts (Freeman, 1942) and zinc allergy in diabetics on zinc insulin preparations have also been described (Feinglos and Jegasothy, 1979).

We thank the Medical Research Council and the Cystic Fibrosis Research Trust for financial support to investigate various aspects of trace metal metabolism in childhood, participation in this work having greatly facilitated the preparation of this paper.

\section{References}

Adams, M. J., Blundell, T. L., Dodson. E. J., Dodson, G. G., Vijayan, M., Baker, E. W., Harding, M. M., Hodgkin, D. C., Rimmer, B., and Sheat, S. (1969). Structure of rhombohedral 2 zinc insulin crystals. Nature, 224, 491-495.

Aggett, P. J., Atherton, D. J., Delves, H. T., Thorn, J. M., Bangham, A., Clayton, B. E., and Harries, J. T. (1978). Studies in acrodermatitis enteropathica. In Trace Element Metabolism in Man and Animals, volume 3, pp. 418-422. 
Edited by M. Kirchgessner. Technische Universitat Munchen: Freising-Weihenstephan.

Alexander, F. W., Clayton, B. E., and Delves, H. T. (1974). Mineral and trace metal balances in children receiving normal and synthetic diets. Quarterly Journal of Medicine, 43, 89-111.

Andersson, K-E., Bratt, L., Denker, H., and Lanner, E. (1976). Some aspects of the intestinal absorption of zinc in man. European Journal of Clinical Pharmacology, 9, 423-428.

Antoniou, L. D., Shalhoub, R. J., Sudhakar, T., and Smith, J. C., Jr (1977). Reversal of uraemic impotence by zinc. Lancet, 2, 895-898.

Arquilla, E. R., Packer, S., Tarmas, W., and Miyamoto, S. (1978). The effect of zinc on insulin metabolism. Endocrinology, 103, 1440-1449.

Atherton, D. J., Muller, D. P. R., Aggett, P. J., and Harries, J. T. (1979). Uptake of zinc by jejunal biopsies in acrodermatitis enteropathica. Clinical Science and Molecular Medicine, 56, 505-507.

Becker, W. M., and Hoekstra, W. G. (1971). The intestinal absorption of zinc. In Intestinal Absorption of Metal Ions, Trace Elements, and Radionuclides, pp. 229-256. Edited by S. C. Skoryna and D. Waldron-Edward. Pergamon Press: Oxford.

Beisel, W. R., Pekarek, R. S., and Wannemacher, R. W. (1976). Homeostatic mechanisms affecting plasma zinc levels in acute stress. In Trace Elements in Human Health and Disease, volume 1, pp. 87-106. Edited by A. S. Prasad. Academic Press: New York.

Berfenstam, R. (1952). Studies on blood zinc. Acta paediatrica Scandinavica, 41, Supplement 87, 37.

Bodzy, P. W., Freeland, J. H., Eppright, M. A., and Tyree, A. (1977). Zinc status in the vegetarian (abstract). Federation Proceedings, 36, 1139.

Brocks, A., Reid, H., and Glazer, R. G. (1977). Acute intravenous zinc poisoning. British Medical Journal, 1, 1390-1391.

Brown, E. D., Chan, W., and Smith, J. C., Jr (1978). Bone mineralization during a developing zinc deficiency. Proceedings of the Society for Experimental Biology and Medicine, 157, 211-214.

Brown, M. A., Thom, J. V., Orth, G. L., Cova, P., and Jaurez, J. (1964). Food poisoning involving zinc contamination. Environmental Health, 8, 657-660.

Carney, S. M., Underwood, B. A., and Loerch, J. D. (1976). Effects of zinc and vitamin A deficient diets on the hepatic mobilisation and urinary excretion of vitamin $A$ in rats. Journal of Nutrition, 106, 1773-1781.

Casey, C. E., Hambidge, K. M., Walravens, P. A., Silverman, A., and Neldner, K. H. (1978). Letter: Zinc binding in human duodenal secretions. Lancet, $2,423$.

Cassens, R. G., Hoekstra, W. G., Faltin, E. C., and Briskey, E. J. (1967). Zinc content and subcellular distribution in red vs white porcine skeletal muscle. American Journal of Physiology, 212, 688-692.

Cavell, P. A., and Widdowson, E. M. (1964). Intakes and excretions of iron, copper, and zinc in the neonatal period. Archives of Disease in Childhood, 39, 496-501.

Cherian, M. G., and Goyer, R. A. (1978). Metallothioneins and their role in the metabolism and toxicity of metals. Life Sciences, 23, 1-10.

Chunn, V. D. (1973). Metal toys containing zinc, and anaemia in children. Clinical Medicine, 80, part 3, 7-10.

Chvapil, M. (1976). Effects of zinc on cells and biomembranes. Medical Clinics of North America, 60, 799-812.

Dauncey, M. J., Shaw, J. C. L., and Urman, J. (1977). The absorption and retention of magnesium, zinc, and copper by low birth weight infants fed pasteurized human breast milk. Pediatric Research, 11, 1033-1039.
Davies, N. T. (1974). The effect of protein synthesis inhibitors on zinc absorption by rat duodenum in vivo (abstract). Journal of Physiology, 244, 38P-39P.

Davies, N. T., and Oppin, S. E. (1979). Studies on the phytate: zinc molar contents in diets as a determinant of $\mathrm{Zn}$ availability to young rats. British Journal of Nutrition, 41, 591-603.

Duncan, J. R., and Hurley, L. S. (1978). Intestinal absorption of zinc; a role for a zinc binding ligand in milk. American Journal of Physiology, 235, E556-E559.

Ebers, G. (1937). The Papyrus Ebers: the Greatest Egyptian Medical Document. Translated by B. Ebbell. Munksgaard: Copenhagen.

Eckhert, C. D., Sloan, M. V., Duncan, J. R., and Hurley, L. S. (1977). Zinc binding: a difference between human and bovine milk. Science, 195, 789-790.

Eggleton, W. G. E. (1939). The zinc content of epidermal structures in beriberi. Biochemical Journal, 33, 403-406.

Evans, G. W. (1976a). Zinc absorption and transport. In Trace Elements in Human Health and Disease, volume 1, pp. 181-187. Edited by A. S. Prasad. Academic Press: New York.

Evans, G. W. (1976b). Transferrin function in zinc absorption and transport. Proceedings of the Society for Experimental Biology and Medicine, 151, 775-778.

Feinglos, M. N., and Jegasothy, B. V. (1979). Insulin allergy due to zinc. Lancet, 1, 122-124.

Fell, B. F., Leigh, L. C., and Williams, R. B. (1973). Cytology of various organs in zinc-deficient rats with particular reference to the frequency of cell division. Research in Veterinary Science, 14, 317-325.

Fernandez-Madrid, F., Prasad, A. S., and Oberleas, D. (1976). Zinc in collagen metabolism. In Trace Elements in Human Health and Disease, volume 1, pp. 257-267. Edited by A. S. Prasad. Academic Press: New York.

Fleming, C. R. Hodges, R. E., and Hurley, L. S. (1976). A prospective study of serum copper and zinc levels in patients receiving total parenteral nutrition. American Journal of Clinical Nutrition, 29, 70-77.

Foley, B., Johnson, S. A., Hackley, B., Smith, J. C., Jr, and Halsted, J. A. (1968). Zinc content of human platelets. Proceedings of the Society for Experimental Biology and Medicine, 128, 265-269.

Freeman, H. E. (1942). Zinc dermatitis: an additional hazard in the aircraft industry. Journal of the American Medical Association, 119, 1016.

Freeman, J. B., Stegink, C. D., Meyer, P. D., Fry, L. K., and Denbesten, C. (1975). Excessive urinary zinc losses during parenteral alimentation. Journal of Surgical Research, 18, $463-469$.

Frommer, D. J. (1975) The healing of gastric ulcers by zinc sulphate. Medical Journal of Australia, 2, 793-796.

Gallery, E. M., Blomfield, J., and Dixon, S. R. (1972). Acute zinc toxicity in haemodialysis. British Medical Journal, 4, 331-333.

Golden, M. H. N., Jackson, A. A., and Golden, B. E. (1977). Effect of zinc on thymus of recently malnourished children. Lancet, 2, 1057-1059.

Golden, M. H. N., Golden, B. E., Harland, P. S. E. G., and Jackson, A. A. (1978). Zinc and immunocompetence in protein-energy malnutrition. Lancet, 1, 1226-1227.

Habib, F. K. (1978). Zinc and the steroid endocrinology of the human prostate. Journal of Steroid Biochemistry, 9, 403-407.

Halsted, J. A., Ronaghy, H. A., Abadi, P., Haghshenass, M., Amirhakemi, G. H., Barakat, R. M., and Rheinhold, J. G. (1972). Zinc deficiency in man: the Shiraz experiment. American Journal of Medicine, 53, 277-284.

Halsted, J. A., Smith, J. C., Jr, and Irwin, M. J. (1974). A 
conspectus of research on zinc requirements of man. Journal of Nutrition, 104, 345-378.

Hambidge, K. M., Hambidge, C., Jacobs, M., and Baum, J. D. (1972). Low levels of zinc in hair, anorexia, poor growth, and hypogeusia in children. Pediatric Research, 6, 868-874.

Hambidge, K. M., Neldner, K. H., and Walravens, P. A. (1975). Letter: Zinc, acrodermatitis enteropathica, and congenital malformations. Lancet, 1, 577-578.

Hambidge, K. M., Walravens, P. A., Brown, R. M., Webster, J., White, S., Anthony, M., and Roth, M. L. (1976). Zinc nutrition in preschool children in the Denver Head Start program. American Journal of Clinical Nutrition, 29, 734-738.

Hambidge, K. M., Walravens, P. A., Neldner, K. H., and Daugherty, N. A. (1978). Zinc, copper, and fatty acids in acrodermatitis enteropathica. In Trace Element Metabolism in Man and Animals, volume 3, pp. 413-417. Edited by M. Kirchgessner. Technische Universitat Munchen: Freising-Weihenstephan.

Hambidge, K. M., Walravens, P. A., Casey, C. E., Brown, R. M., and Bender, C. (1979). Plasma zinc concentrations of breast fed infants. Journal of Pediatrics, 94, 607-608.

Harries, J. T. (1977). Selective inborn errors of absorption. In Essentials of Paediatric Gastroenterology, pp. 199-209. Edited by J. T. Harries. Churchill Livingstone: London.

Harrison, M. E., Walls, C., Korslund, M. K., and Ritchey, S. J. (1975). An evaluation of mineral losses through arm sweat of pre-adolescent children. American Journal of Clinical Nutrition, 29, 842-846.

Hartoma, T. R., Nahoul, K., and Netter, A. (1977). Letter: Zinc, plasma androgens, and male sterility. Lancet, 2 , $1125-1126$.

Heinersdorff, N., and Taylor, T. G. (1979). Concentration of zinc in the hair of schoolchildren. Archives of Disease in Childhood, 54, 958-960.

Henkin, R. I. (1978). Zinc dependent control of food intake, taste, and smell function. In Trace Element Metabolism in Man and Animals, volume 3, pp. 190-198. Edited by M. Kirchgessner. Technische Universitat Munchen: Freising-Weihenstephan.

Henkin, R. I., Lippoldt, R. E., Bilstad, J., and Edelhoch, H. (1975a). A zinc protein isolated from human parotid saliva. Proceedings of the National Academy of Sciences of the United States of America, 72, 488-492.

Henkin, R. I., Patten, B. M., Re, P. K., and Bronzert, D. A. (1975b). A syndrome of acute zinc loss. Archives of Neurology, 32, 745-751.

Hsu, J. M., and Anthony, W. L. (1971). Impairment of cystine ${ }^{35} \mathrm{~S}$ incorporation into skin protein by zinc deficient rats. Journal of Nutrition, 101, 445-452.

Huber, A. M., and Gershoff, S. N. (1975). Effects of zinc deficiency on the oxidation of retinol and ethanol in rats. Journal of Nutrition, 105, 1486-1490.

Hurley, L. S., and Swennerton, H. (1971). Lack of mobilization of bone and liver zinc under terotogenic conditions of zinc deficiency in rats. Journal of Nutrition, 101, 597-604.

Hurley, L. S., and Mutch, P. B. (1973). Prenatal and postnatal development after transitory gestational zinc deficiency in rats. Journal of Nutrition, 103, 649-656.

Hurley, L. S., Duncan, J. R., Eckhert, C. D., and Sloan, M. V. (1978). Zinc binding ligands in milk and their relationship to neonatal nutrition. In Trace Element Metabolism in Man and Animals, volume 3, pp. 449-451. Edited by $M$. Kirchgessner. Technische Universitat Munchen: FreisingWeihenstephan.

Jameson, S. (1976). Effects of zinc deficiency in human reproduction. Acta medica Scandinavica, Supplement 593.

Kirchgessner, M., Roth, H. P., and Weigand, E (1976).
Biochemical changes in zinc deficiency. In Trace Elements in Human Health and Disease, volume 1, pp. 189-225. Edited by A. S. Prasad. Academic Press: New York.

Lancet (1978). Editorial: A radical approach to zinc. Lancet, 1, 191-192.

Lombeck, I., Schnippering, H. G., Ritzl, F., Feinendegen, L. E., and Bremer, H. J. (1975). Letter: Absorption of zinc in acrodermatitis enteropathica. Lancet, 1,855 .

McMahon, D. (1974). Chemical messengers in development: a hypothesis. Science, 185, 1012-1021.

Mazé, P. (1914). Influences respectives des élements de la solution minéral a sur le developpement du mais. Annales del'Institut Pasteur, 28, 21-69.

Methfessel, A. H., and Spencer, H. (1973). Zinc metabolism in the rat. I. Intestinal absorption of zinc. Journal of Applied Physiology, 34, 58-62.

Michaëlsson, G., Juhlin, L., and Vahlquist, A. (1977). Effect of oral zinc and vitamin $\mathrm{A}$ in acne. Archives of Dermatology, 113, 31-36.

Momcilovic, B., Belonje, B., Giroux, A., and Shah, B. G. (1976). Bioavailability of zinc in milk and soy proteinbased infant formulas. Journal of Nutrition, 106, 913-917.

Moore, R. (1978). Bleeding gastric erosion after oral zinc sulphate. British Medical Journal, 1, 754.

Moynahan, E. J. (1974). Acrodermatitis enteropathica: a lethal inherited human zinc deficiency disorder. Lancet, 1, 399-400.

Moynahan, E. J., and Barnes, P. M. (1973). Zinc deficiency and a synthetic diet for lactose intolerance. Lancet, 1 , 676-677.

Murphy, J. V. (1970). Intoxication following ingestion of elemental zinc. Journal of the American Medical Association, 212, 2119-2120.

National Research Council Food and Nutrition Board (1974). Recommended Dietary Allowances, eighth revised edition. National Academy of Sciences: Washington.

Nickolson, V. J., and Veldstra, H. (1972). The influence of various cations on the binding of colchicine by rat brain homogenates. Stabilisation of intact neurotubules by zinc and cadmium ions. FEBS Letters, 23, 309-313.

Oelshlegel, F. J., Jr, and Brewer, G. J. (1977). Absorption of pharmacologic doses of zinc. In Zinc Metabolism: Current Aspects in Health and Disease, pp. 299-311. Edited by G. J. Brewer and A. S. Prasad. Liss: New York.

Picciano, M. F., and Guthrie, H. A. (1976). Copper, iron, and zinc contents of mature human milk. American Journal of Clinical Nutrition, 29, 242-254.

Prasad, A. S., Schulert, A. R., Sandstead, H. H., Miale, A., Jr, and Farid, Z. (1963). Zinc, iron, and nitrogen content of sweat in normal and deficient subjects. Journal of Laboratory and Clinical Medicine, 62, 84-89.

Prasad, A. S., and Oberleas, D. (1970). Binding of zinc to amino acids and serum proteins in vitro. Journal of Laboratory and Clinical Medicine, 76, 416-425.

Prasad, A. S., and Oberleas, D. (1973). Ribonuclease and deoxyribonuclease activities in zinc deficient tissues. Journal of Laboratory and Clinical Medicine, 82, 461-466.

Prasad, A. S., Brewer, G. J., Schoomaker, E. B., and Rabbani, P. (1978a). Hypocupremia induced by zinc therapy in adults. Journal of the American Medical Association, 240, 2166-2168.

Prasad, A. S., Rabbani, P., Abasii, A., Bowersox, E., and Spivey Fox, M. R. (1978b). Experimental zinc deficiency in humans. Annals of Internal Medicine, 89, 483-490.

Rabbani, P., and Prasad, A. S. (1978). Plasma ammonia and liver ornithine transcarbamyl transferase activity in zinc deficient rats. American Journal of Physiology, 235, E203-E206.

Raulin, J. (1869). Études cliniques sur la vegetation. Annales des Sciences Naturelles: Botanique, 11, 93-299. 
Richards, M. P., and Cousins, R. J. (1975) Mammalian zinc homeostasis; requirement for RNA and metallothionein synthesis. Biochemical and Biophysical Research Communications, 64, 1215-1223.

Richards, M. P., and Cousins, R. J. (1976). Metallothionein and its relationship to the metabolism of dietary zinc in rats. Journal of Nutrition, 106, 1591-1599.

Riordan, J. F., and Vallee, B. L. (1976). Structure and function of zinc metalloenzymes. In Trace Elements in Human Health and Disease, volume 1, chapter 14, pp. 227-256. Edited by A. S. Prasad. Academic Press: New York.

Rose, G. A., and Willden, E. G. (1972). Whole blood, red cell, and plasma total and ultrafiltrable zinc levels in normal subjects and in patients with chronic renal failure with and without haemodialysis. British Journal of Urology, 44, 281-286.

Rühl, H., and Kirchner, H. (1978). Monocyte-dependent stimulation of human T-cells by zinc. Clinical and Experimental Immunology, 32, 484-488.

Sandstead, H. H., Strobel, D. A., Logan, G. M., Jr, Marks, E. O., and Jacob, R. A. (1978). Zinc deficiency in pregnant rhesus monkeys: effects on behavior of infants. American Journal of Clinical Nutrition, 31, 844-849.

Sever, L. E., and Emanuel, I. (1973). Letter: Is there a connection between maternal zinc-deficiency and congenital malformations of the central nervous system? Teratology, 7, 117-118.

Simkin, P. A. (1976). Oral zinc sulphate in rheumatoid arthritis. Lancet, 2, 539-542.

Sivasubramanian, K. N., and Henkin, R. I. (1978). Behavioral and dermatologic changes and low serum zinc and copper concentrations in two premature infants after parenteral alimentation. Journal of Pediatrics, 93, 847-851.

Spencer, H., Rosoff, B., Lewin, I., and Samachson, J. (1966). Studies of zinc 65 metabolism in man. In Zinc Metabolism, pp. 339-362. Edited by A. S. Prasad. Thomas: Springfield.

Stake, P. E., Miller, W. J., Blackmon, D. M., Gentry, R. P., and Neathery, M. W. (1974). Role of pancreas in endogenous zinc excretion in the bovine. Journal of Nutrition, 104, 1279-1284.

Thiers, R. E., and Vallee, B. L. (1957). Distribution of metals in subcellular fractions of rat liver. Journal of Biological Chemistry, 226, 911-920.
Thorn, J. M., Aggett, P. J., Delves, H. T., and Clayton, B. E. (1978). Mineral and trace metal supplement for use with synthetic diets based on comminuted chicken. Archives of Disease in Childhood, 53, 931-938.

Todd, W. R., Elvehjem, C. A., and Hart, E. B. (1934). Zinc in the nutrition of the rat. American Journal of Physiology, 107, 146-156.

Underwood, E. J. (1977). Trace Elements in Human and Animal Nutrition, fourth edition, pp. 196-242. Academic Press: New York.

Vallee, B. L. (1977). Zinc biochemistry in normal and neoplastic growth processes. Experientia, 33, 600-601.

Vallee, B. L., and Gibson, J. G. (1948). Zinc content of normal human whole blood, plasma, leucocytes, and erythrocytes. Journal of Biological Chemistry, 176, 445457.

van Caillie, M., Deganhart, H., Luijendijk, I., and Fernandes, J. (1978). Zinc content of intravenous solutions. Lancet, 2, 200-201.

Vuori, E., and Kuitunen, P. (1979). The concentrations of copper and zinc in human milk. Acta paediatrica Scandinavica, 68, 33-37.

Walravens, P. A., and Hambidge, K. M. (1976). Growth of infants fed a zinc supplemented formula. American Journal of Clinical Nutrition, 29, 1114-1121.

Weston, W. L., Huff, J. C., Humbert, J. R., Hambidge, K. M., Neldner, K. H., and Walravens, P. A. (1977). Zinc correction of defective chemotaxis in acrodermatitis enteropathica. Archives of Dermatology, 113, 422-425.

Widdowson, E. M., McCance, R. A., and Spray, C. M. (1951). The chemical composition of the human body. Clinical Science, 10, 113-125.

Widdowson, E. M., and Spray, C. M. (1951). Chemical development in utero. Archives of Disease in Childhood, 26, 205-214.

Wootton, A. C. (1910). Chronicles of Pharmacy, volume 1, pp. 426-428. Macmillan: London.

World Health Organisation (1973). Trace Elements in Human Nutrition. UN/WHO Technical Report Series 532. WHO: Geneva.

Correspondence to Dr P. Aggett, Department of Physiology, Marischal College, Aberdeen AB9 1AS. 